\title{
Hepatitis C: a review for primary care physicians
}

\author{
Tom Wong, Samuel S. Lee
}

\section{ABSTRACT}

Primary care physicians see many of the estimated 250000 Canadians chronically infected with the hepatitis $C$ virus (HCV). Of this number, about one-third are unaware they are infected, which constitutes a large hidden epidemic. They continue to spread HCV unknowingly and cannot benefit from advances in antiviral therapy that may clear them of the virus. Many HCV-infected people remain asymptomatic, which means it is important to assess for risk factors and test patients accordingly. The third-generation enzyme immunoassay for HCV antibodies is a sensitive and specific test, although the presence of the virus can be confirmed by polymerase chain reaction testing for HCV RNA in some circumstances. Pegylated interferon- $\alpha$ and ribavirin combination therapy clears the virus in about $45 \%-80 \%$ of patients, depending on viral genotype. Preventive strategies and counselling recommendations are also reviewed.

CMAJ 2006;174(5):649-59

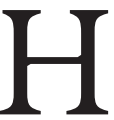
epatitis C virus (HCV), which was first characterized in the late I980s, is an RNA flavivirus with 6 major genotypes and more than 50 subtypes. ${ }^{1}$ Genotype $\mathrm{I}$ is predominant in Canada, accounting for over $60 \%$ of cases, followed by type 2 (II $\%-16 \%)$, type $3(6 \%-$ $14 \%)$, and the uncommon types 4,5 and $6(<5 \%) .{ }^{2-4}$ It is estimated that $123-170$ million people ${ }^{5,6}$ worldwide are living with HCV infection, of whom 250000 (0.8\%) are in Cana$\mathrm{da},{ }^{7}$ and that about 5000 Canadians are newly infected each year. ${ }^{7}$ There have been major antiviral treatment advances in recent years. No vaccine is available, although vaccine research is underway. The goal to reduce the number of people living with hepatitis $\mathrm{C}$ and its complications cannot be achieved without the contributions of public health, specialty care and primary care clinicians. The primary care approach to the prevention, screening, diagnosis and management of HCV infection among adult patients is the focus of this review.

\section{Epidemiologic features}

HCV is primarily transmitted parenterally. In Canada, recreational injection drug use (IDU) has been and continues to be the dominant mode of HCV acquisition. Data from the 8centre Laboratory Centre for Disease Control Sentinel Surveil- lance from 1993 to 1995 were analyzed for a detailed risk factor profile of $585 \mathrm{HCV}$-infected patients. ${ }^{8}$ Of these patients, $67 \%$ had a history of IDU, $17 \%$ of both IDU and blood transfusion and $6 \%$ of transfusion but no IDU. Therefore, $84 \%$ of $\mathrm{HCV}$-infected patients involved this study admitted to IDU. In a sample of 698 patients in Vancouver between 1995 and I996, 70\% had a history of IDU and I6\% had received a blood transfusion. The proportion of people with both risk factors was not reported. ${ }^{8}$ In the largest published Canadian series of 239 patients from a Calgary hepatology practice between 1995 and $1999,74 \%$ had a history of IDU or cocaine inhalations. ${ }^{9}$ IDU was also the predominant risk factor in 2 smaller series, from an Ottawa gastroenterology practice ${ }^{10}$ and the Prince Edward Island Public Health Unit. ${ }^{11}$ It thus appears that IDU is the route of transmission for about $70 \%-80 \%$ of the recent HCV cases in Canada. Practitioners must ask about any history of IDU, even a single episode in the remote past, by patients confirmed or suspected to be infected with HCV. Many patients are surprised to discover that they are chronically infected with a virus that was transmitted several decades earlier, during an experience that happened only once and that seemed to be innocuous or trivial.

In the larger cities of Canada, the second largest risk factor is travel or residence in a region in which HCV infection is endemic (Table I). In many countries, especially in the past, parenteral injections were done with reusable glass syringes and needles. Compelling epidemiologic data indicate that such health care-related parenteral injections account for the high HCV seroprevalence rates in areas such as Egypt, Pakistan, Asia, and, in the past, southern Italy and Japan. ${ }^{8,12-32}$ Sadly, such transmission continues today in many resource-poor countries; the World Health Organization estimates that globally 8-I2 billion injections are given every year, with more

Table 1: Estimated prevalence of hepatitis $C$ by region ${ }^{6}$

\begin{tabular}{lcc}
\hline Region & $\begin{array}{c}\text { Infected population, } \\
\text { million }\end{array}$ & $\begin{array}{c}\text { Prevalence } \\
\text { rate, \% }\end{array}$ \\
\hline Europe & 8.9 & 1.0 \\
Americas & 13.1 & 1.7 \\
Southeast Asia & 32.3 & 2.2 \\
Western Pacific & 62.2 & 3.9 \\
Eastern Mediterranean & 21.3 & 4.6 \\
Africa & 31.9 & 5.3 \\
\hline
\end{tabular}


than half of these being unsafe in the developing world; $2-5$ million HCV infections annually are attributable to unsafe health care injections. ${ }^{18-20,28,33}$ Some countries have massive HCV problems: about 10\% of the Pakistani population is infected, as is about $15 \%-20 \%$ of the population in Egypt. ${ }^{12,16}$ Most patients in Egypt became infected during attempts to eradicate endemic bladder schistosomiasis by mass parenteral antischistosomal treatment programs. ${ }^{16,17}$

\section{Box 1: Risk factors for hepatitis C virus (HCV)} infection ${ }^{36,63,64}$

High risk of HCV infection is associated with:

- Any history of injection drug use

- Contaminated blood or blood products or organ transplantation before July 1990

- Incarceration

- Needlestick or sharp injuries

- Procedures (e.g., injection, vaccination, surgery, transfusion, ceremonial rituals) involving reuse or sharing of contaminated equipment in parts of the world with high HCV prevalence (see Table 1)

- Nonsterile contaminated tattooing or body piercing equipment

- Receiving hemodialysis

- Sharing personal items contaminated with blood with an $\mathrm{HCV}$-infected person (e.g., razors, nail clippers, toothbrush)

- Sharing contaminated intranasal cocaine equipment

- Hepatitis B virus infection

- HIV infection

- Children born to mother with HCV infection*

- Undiagnosed liver disease

Moderate risk of HCV infection is associated with:

- A sexual partner with HCV

- Multiple sexual partners

- Sexually transmitted infection, including HIV and lymphogranuloma venereum

- Traumatic sex that involves the potential for mucosal tearing (sex toys, fisting)

- Vaginal sex during menstruation

Transmission of hepatitis C virus is NOT associated with:

- Coughing

- Food

- Water

- Sharing eating utensils

- Hugging or kissing

- Shaking hands

- Toilet seats

- Other casual contact

- Breastfeeding (unless nipples are cracked and bleeding)

- Oral sex (unless blood exposure is involved)

*Pregnancy is not contraindicated, but fetal scalp monitoring or prolonged labour after rupture of membrane should be avoided. Interferon and ribavirin are contraindicated during pregnancy. Whether $\mathrm{C}$-sections prevent vertical transmission remains unknown.
Transmission through blood products and organ transplantation has been virtually eliminated in North America since 1990, following the exclusion of high-risk donors, new viral inactivation procedures, and the development of increasingly more sensitive HCV screening tests. ${ }^{34-36}$ The current risk of HCV infection from blood transfusion in Canada is estimated to be less than I in 3000000 units transfused. ${ }^{37}$

Sexual and vertical transmission of HCV is uncommon and much less efficient than with hepatitis B virus or HIV. ${ }^{32,38,39}$ High HCV prevalence is found among sex workers, but it is often linked to drug injection and to people who have multiple partners. ${ }^{40-42}$ In Western countries, the prevalence among long-term sexual partners with continuing sexual exposure and no other risk factors is relatively low $(<5 \%)$. $^{43-45}$ Recently, apparent sexual transmission of HCV has been increasingly reported in Europe among gay men who are not injection drug users; such men have a higher prevalence of fisting and of lymphogranuloma venereum, HIV and other sexually transmitted infections. ${ }^{46-49}$ The vertical HCV transmission risk is estimated to be about $4 \%-7 \%$, and it rises with HIV coinfection and a high maternal HCV viral load..$^{50-52}$ $\mathrm{HCV}$ is not transmitted by breastfeeding. ${ }^{52,53}$

Risk of HCV transmission through needlestick injury is in

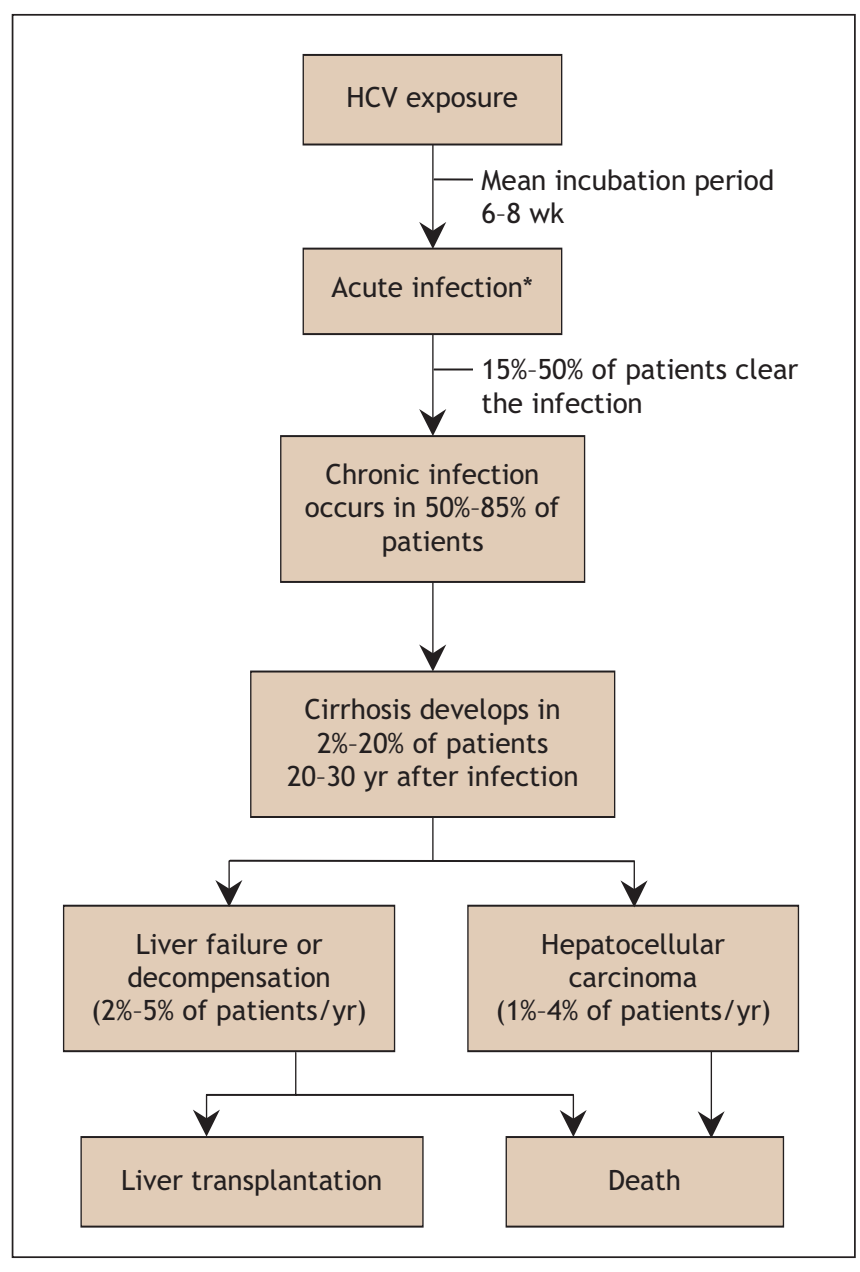

Fig. 1: Natural history of hepatitis C virus (HCV) infection. ${ }^{68}$ *Note that $60 \%-75 \%$ of patients are asymptomatic at this stage. 
the order of $\mathrm{I} \%-3 \%$, compared with $30 \%$ for hepatitis B virus and $0.3 \%$ for HIV..$^{54-56}$ Transmission has also been associated with organ transplantation, hemodialysis, tattooing, and sharing contaminated equipment in parts of the world where the HCV prevalence is high. ${ }^{12-31,57-60}$ Sharing contaminated intranasal cocaine equipment (straw or rolled-up money) may be associated with transmission. ${ }^{61-63}$ Coughing, hugging, kissing, shaking hands, sharing eating utensils or casual contact does not transmit HCV, nor is it transmitted through food or water (Box I). The mean incubation period is $6-8$ weeks. ${ }^{65-67}$

\section{Natural history and clinical manifestations}

The natural history of HCV infection is shown in Fig. I. Most infected people $(60 \%-75 \%)$ do not experience symptoms when acutely infected. ${ }^{69}$ For those with symptomatic acute infections, the manifestations are similar to those of hepatitis A or B virus infection: malaise, fatigue, lethargy, anorexia, abdominal pain, jaundice, mild hepatosplenomegaly, maculopapular rash and arthralgia. These symptoms may last for 2-I2 weeks. Patients with acute viral hepatitis often report a transient distaste for cigarettes or alcohol or both. Fulminant hepatitis is very rare in the acute infection stage. ${ }^{63,68,70}$ It must be emphasized that physicians, unless they work at an innercity clinic with a high prevalence of active injection drug users, are unlikely to come across patients with symptoms of acute hepatitis. This is because the vast majority of acute HCV cases are asymptomatic or have only mild flu-like symptoms with little or no jaundice.

The differential diagnosis of a symptomatic acute HCV infection includes alcohol and other substance use, medication or supplement use, hepatitis A, B, D or E, primary biliary cirrhosis, autoimmune hepatitis, fatty liver, hemochromatosis, Wilson's disease and $\alpha-\mathrm{I}$ antitrypsin deficiency.

A minority of newly infected patients ( $15 \%-50 \%$ ) will clear the infection, but in most $(50 \%-85 \%)$ the infection will become chronic. The risk of chronicity after acute infection is less $(50 \%-70 \%)$ with community-acquired infections and higher $(70 \%-85 \%)$ in post-transfusion cases. Some patients with chronic infection experience malaise, nausea, abdominal pain and pruritis. Fluctuating alanine transaminase levels are characteristic. The physical examination may reveal signs of liver disease such as spider angiomata, palmar erythema and telangiectasia. Much later in the course, if advanced cirrhosis develops, jaundice, splenomegaly, ascites, esophageal varices and hepatic encephalopathy may be noted. Extrahepatic manifestations are uncommon and may include mixed essential cryoglobulinemia, membranous or membranoproliferative glomerulonephritis, non-Hodgkin's lymphoma, Sjögren's syndrome, lichen planus and porphyria cutanea tarda. ${ }^{71-80}$

Chronic infection causes mild chronic inflammation of the liver. Ongoing cycles of inflammation, necrosis and apoptosis eventually lead to scarring (fibrosis) and, ultimately, severe bridging fibrosis with nodular regeneration. This, of course, is cirrhosis. The rate at which fibrosis progresses to cirrhosis in chronic HCV infection is relatively slow compared with that of many other liver diseases. Factors that increase the progression rate include sex (men $>$ women), older age at infection acquisition, longer duration of infection, immune suppression (e.g., HIV-HCV coinfection), chronic hepatitis B coinfection, moderate or heavy alcohol use, and obesity. ${ }^{68,81-86}$ Over $20-30$ years of infection, the risk of cirrhosis is $2 \%-$

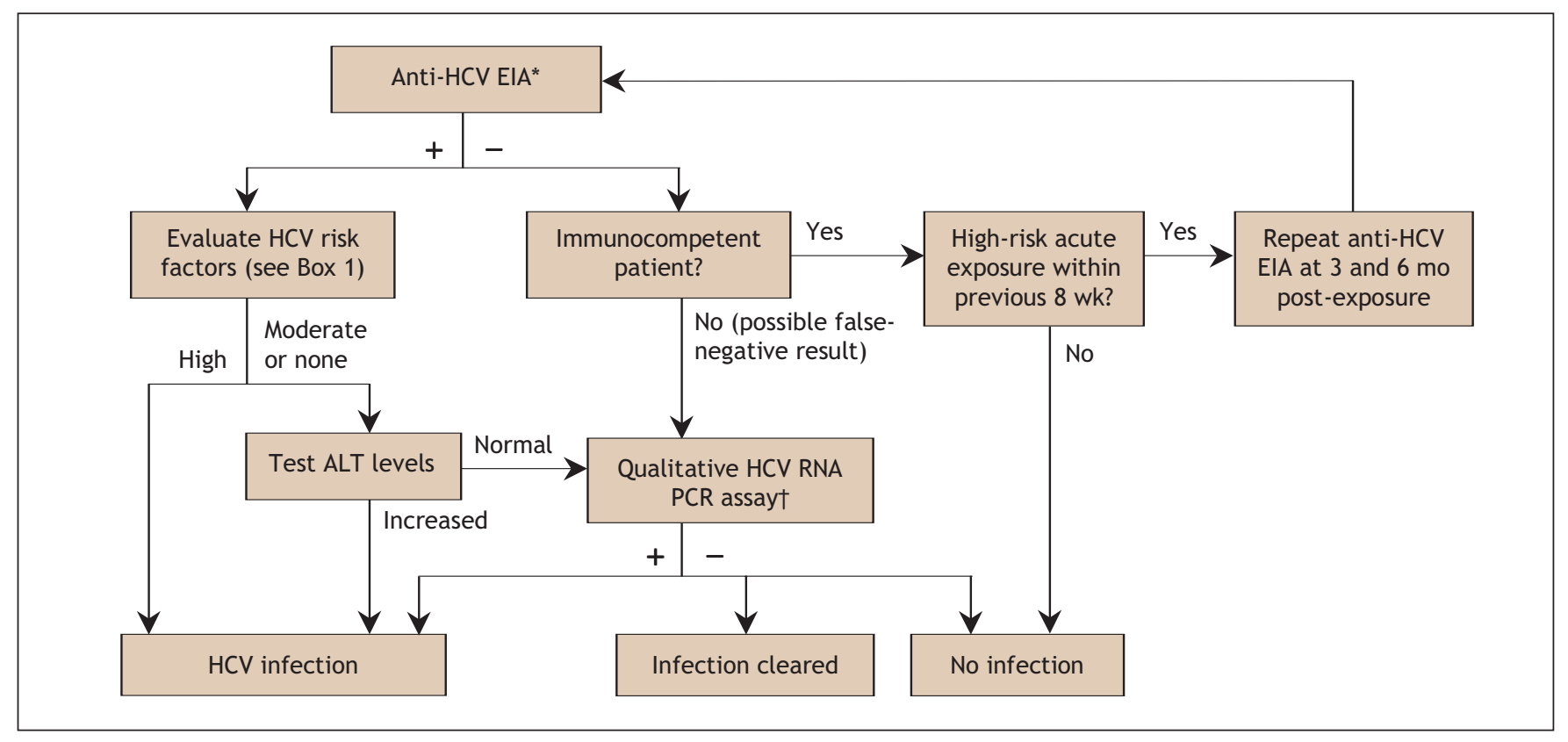

Fig. 2: Algorithm for testing for hepatitis $C$ infection. ${ }^{63,93,98}{ }^{*} \mathrm{If}$ the result of the anti-HCV EIA is indeterminate, a qualitative HCV RNA PCR is required. TThe threshold for a positive HCV RNA assay result is $>50 \mathrm{IU} / \mathrm{mL}$. HCV $=$ hepatitis $\mathrm{C}$ virus, anti-HCV $=\mathrm{HCV}$ antibodies, $\mathrm{EIA}=$ enzyme immunoassay, $\mathrm{ALT}=$ alanine transferase, $\mathrm{PCR}=$ polymerase chain reaction. 
Box 2: Contraindications for hepatitis C therapy with interferon and ribavirin ${ }^{93,100}$

\section{Absolute contraindications}

- Age $<3$ yr

- Poor compliance

- Decompensated liver disease*

- Ongoing and untreated substance abuse

- Pregnancy or nonadherence to contraceptive use during treatment and for 6 mo afterward

- Coexisting medical conditions: - uncontrolled seizure disorder uncontrolled severe psychiatric disorder certain autoimmune diseases, including autoimmune hepatitis and systemic lupus erythematosus

\section{Relative contraindications}

- Solid organ transplantation (except liver)

- Coexisting medical conditions: - severe anemia (hemoglobin level $<100 \mathrm{~g} / \mathrm{L}$ ) neutropenia (neutrophil count $<0.75 \times 10^{9} / \mathrm{L}$ ) thrombocytopenia (platelet count $<40 \times 10^{9} / \mathrm{L}$ ) hemoglobinopathy uncontrolled heart disease (e.g., angina, congestive heart failure, significant arrhythmias)

cerebrovascular disease

advanced renal failure (creatinine clearance $<50 \mathrm{ml} / \mathrm{min}$ )

*Includes esophageal varices, ascites, encephalopathy.

$20 \%$; after cirrhosis has developed, the risk of hepatocellular carcinoma is $1 \%-4 \%$ each year. ${ }^{68,87}$ Hepatitis C infection is currently the leading indication for liver transplantation in North America, ${ }^{63,88,89}$ not because of rapid progression to cirrhosis and end-stage liver failure but mostly because of the large number of people with chronic infection (3 million in North America), many of whom have been infected for 3 or 4 decades.

\section{Serologic testing}

Although there are no data evaluating the efficacy of screening and treatment on the basis of long-term outcomes (e.g., liver transplant demand, survival), ${ }^{90,91}$ the Canadian Consensus Conference on Viral Hepatitis Management and the US Centers for Disease Control and Prevention and National Institutes of Health recommend the serologic testing of people at increased risk of hepatitis C infection (Box I)..$^{63,70,92,93}$ This recommendation is based on newer antiviral combination treatment being able to clear the virus in $45 \%-80 \%$ of cases, often with histologic improvement, ${ }^{94}$ and on counselling and other interventions (e.g., restriction of alcohol use and other risky practices, hepatitis $A$ and $B$ immunization, treatment of coinfections) reducing disease progression and secondary transmission. ${ }^{63,70,92,93,95-97}$

It is estimated that about one-third of Canadians with chronic HCV infection, or about 90 ooo Canadians, remain unaware of their infection. ${ }^{7}$ For some, $\mathrm{HCV}$ infection is diagnosed as a result of a work-up for clinical manifestations or abnormal liver enzyme levels. However, most people are asymptomatic and can be identified only by screening for risk factors (Box I).

The initial laboratory test is usually an enzyme immunoassay (EIA) for HCV antibodies (anti-HCV) (Fig. 2). The first anti-HCV EIA became available in I990, but it had relatively poor sensitivity and specificity. In I992, a second-generation EIA dramatically improved both sensitivity and specificity. The third-generation anti-HCV EIA, in use since the midI 990 os, has a sensitivity of $95 \%-99 \%$ and can detect HCV antibodies $6-8$ weeks after exposure. ${ }^{63,98,99}$ Polymerase chain reaction (PCR) methods detect the presence of HCV RNA much earlier, at I-3 weeks after exposure. ${ }^{63}$

If the EIA anti-HCV test result is positive, infection can be confirmed with a highly sensitive PCR-based qualitative HCV RNA assay. However, such confirmatory testing is expensive and unnecessary in routine primary care practice. For example, virtually all patients who have a positive anti-HCV test result, a history of risk and abnormal serum alanine transferase values will be viremic (i.e., they will have a positive HCV RNA test result). There is therefore no point in confirming viremia with a HCV RNA test until or unless such a patient is about to start antiviral therapy. Patients who should be tested for HCV RNA include those whose antiHCV EIA result was inconclusive; immunocompromised patients (e.g., those with HIV or who are undergoing hemodialysis) who may not generate antibodies to infection; patients who are thought to be in a period of acute infection, when the PCR test result will be positive but antibodies have not yet developed; and patients with a positive anti-HCV test result but persistently normal alanine transferase levels. A significant minority of patients who have HCV antibodies and persistently normal liver chemistry test results (especially if alanine transferase values are in the lower half of the normal range) have spontaneously cleared their acute HCV infection but will continue to have detectable HCV antibodies for an indefinite period..$^{63,93,98}$

\section{Management}

If a patient has hepatitis $\mathrm{C}$, look specifically for contraindications to antiviral therapy (Box 2) in the clinical evaluation and for signs of liver disease such as spider nevi and palmar erythema. Jaundice, hepatosplenomegaly, ascites, encephalopathy and gastroesophageal varices are signs of more advanced disease. Baseline laboratory test results should be obtained (Table 2).

The patient can then be referred to a specialist to assess management options. The complex decision whether to initiate antiviral therapy needs to be based on factors such as the patient's interest, barriers to adherence, clinical and laboratory findings, probability of disease progression without therapy, odds of treatment success, likelihood of adverse effects and absolute and relative contraindications to therapy (Box 2). Genotyping will be performed if the patient is a candidate for antiviral treatment. For patients with genotype I HCV, a 
liver biopsy will usually be arranged if no contraindications exist, and the "viral load" will be measured. Patients with genotype 2 or 3 are expected to have a high likelihood of treatment success $(75 \%-85 \%)$ and therefore may not require a liver biopsy and do not require a baseline viral load measurement. ${ }^{63,98}$ Data are limited for other genotypes because these genotypes are uncommon and because the breakdown of genotypes is not available in the randomized trials conducted in Western countries. Two trials involving patients with genotype 4 in Egypt, where the genotype constitutes up to $90 \%$ of HCV infections, have just been published. ${ }^{102,103}$ This genotype is dominant in the Middle East, and treatment recommendations have recently been published. ${ }^{104} \mathrm{HCV}$ genotype 4 generally responds to treatment as genotype I does, and the current recommendation is to treat it in the same manner ( 48 weeks of therapy). ${ }^{104}$

Genotype $5 \mathrm{HCV}$ is common in southern Africa and distinctly rare elsewhere. Genotype 6 is generally limited to Southeast Asia. In the absence of clinical trials or even anecdotal series with significant numbers of these genotypes, we recommend treating these genotypes in the same way as genotype $\mathrm{I}$.

\section{Antiviral treatment}

Fig. 3 shows the algorithm for antiviral therapy. In 2004 the Canadian Consensus Conference on the management of viral hepatitis recommended that all patients with hepatitis $\mathrm{C}$ be assessed for antiviral therapy. ${ }^{93}$ This includes patients with sporadically or persistently normal alanine transferase levels. In the past, patients with normal levels had generally not received therapy or even been referred to specialists. However, we now recognize that such patients can have serious underlying liver fibrosis and a treatment response similar to patients with elevated levels. Successful antiviral treatment has been shown to achieve biochemical, viral and histologic responses and to decrease the risk of hepatocellular carcinoma. ${ }^{63,92,95,96,107-112}$ However, as mentioned earlier, there are no prospective data on outcomes following long-term therapy. Sustained virologic response is the primary marker of therapeutic outcome, and it is achieved if serum HCV RNA levels are below the level of detection $(\leq 50 \mathrm{IU} / \mathrm{mL}) 6$ months after therapy is completed. As a marker, sustained virologic response strongly predicts viral clearance from the liver, marked histologic improvement and the absence of relapse in the ensuing years. ${ }^{107}$ In other words, many patients who achieve sustained virologic response appear to be virologically cured.

Treatment success rates with antiviral therapy have improved significantly over the past decade. Pegylation of interferon (the addition of inert polyethylene glycol to standard interferon- $\alpha$ ) reduces drug clearance rates, which allows dosing to be reduced to one time per week, compared with 3 times per week for standard interferon. Standard interferon- $\alpha$ has a circulating half-life of about 4 hours, and this is dramatically increased to about 80 hours with peginterferon $\alpha-2 a$ and about 36 hours with peginterferon $\alpha-2 b$.

Combining weekly subcutaneous peginterferon- $\alpha$ therapy with daily oral ribavirin therapy is more effective than monotherapy with peginterferon or combination therapy with standard interferon and ribavirin. A summary of the results of randomized controlled trials of HCV therapies is presented in Table 3.

Patients must be monitored closely for a variety of adverse

Table 2: Baseline investigations associated with hepatitis $C$ antiviral therapy*93,101

\begin{tabular}{|c|c|}
\hline Test & Comments \\
\hline Complete blood count including platelet count & $\begin{array}{l}\text { Baseline evaluation is needed because interferon is associated with bone } \\
\text { marrow suppression and ribavirin is associated with hemolytic anemia }\end{array}$ \\
\hline $\begin{array}{l}\text { Prothrombin time, international normalized } \\
\text { ratio; albumin; alanine aminotransferase; } \\
\text { bilirubin; alkaline phosphatase }\end{array}$ & Assesses baseline hepatic function and inflammation \\
\hline Glucose & Interferon therapy may cause hyperglycemia \\
\hline Creatinine and urinalysis & Identifies renal disease, which is rarely associated with HCV infection \\
\hline $\begin{array}{l}\text { Thyroid-stimulating hormone and antinuclear } \\
\text { antibodies }\end{array}$ & Identifies autoimmune diseases that can be exacerbated by interferon \\
\hline $\begin{array}{l}\text { Serum } \beta \text {-human chorionic gonadotropin (in } \\
\text { women of childbearing potential) }\end{array}$ & To rule out pregnancy, an absolute contraindication to treatment \\
\hline HIV & Detects coinfection \\
\hline $\begin{array}{l}\text { Hepatitis B surface antigen, antibody to } \\
\text { hepatitis B surface antigen }\end{array}$ & Detects coinfection and immunity status \\
\hline Chlamydia, gonorrhea, syphilis & Perform in patients at increased risk of sexually transmitted infection \\
\hline Abdominal ultrasound & Assesses for evidence of portal hypertension, cirrhosis and malignant disease \\
\hline $\begin{array}{l}\text { Electrocardiogram if history of cardiac disease } \\
\text { or age }>50 \mathrm{yr}\end{array}$ & $\begin{array}{l}\text { Arrhythmias may occur with interferon. Ribavirin has no direct cardiovascular } \\
\text { effects, but anemia may exacerbate pre-existing coronary artery disease. }\end{array}$ \\
\hline
\end{tabular}

Note: $\mathrm{HCV}=$ hepatitis $\mathrm{C}$ virus.

*Recommendations for investigations during antiviral therapy are included in Appendix 1, available at www.cmaj.ca/cgi/content/full/cmaj.1030034/DC1. 


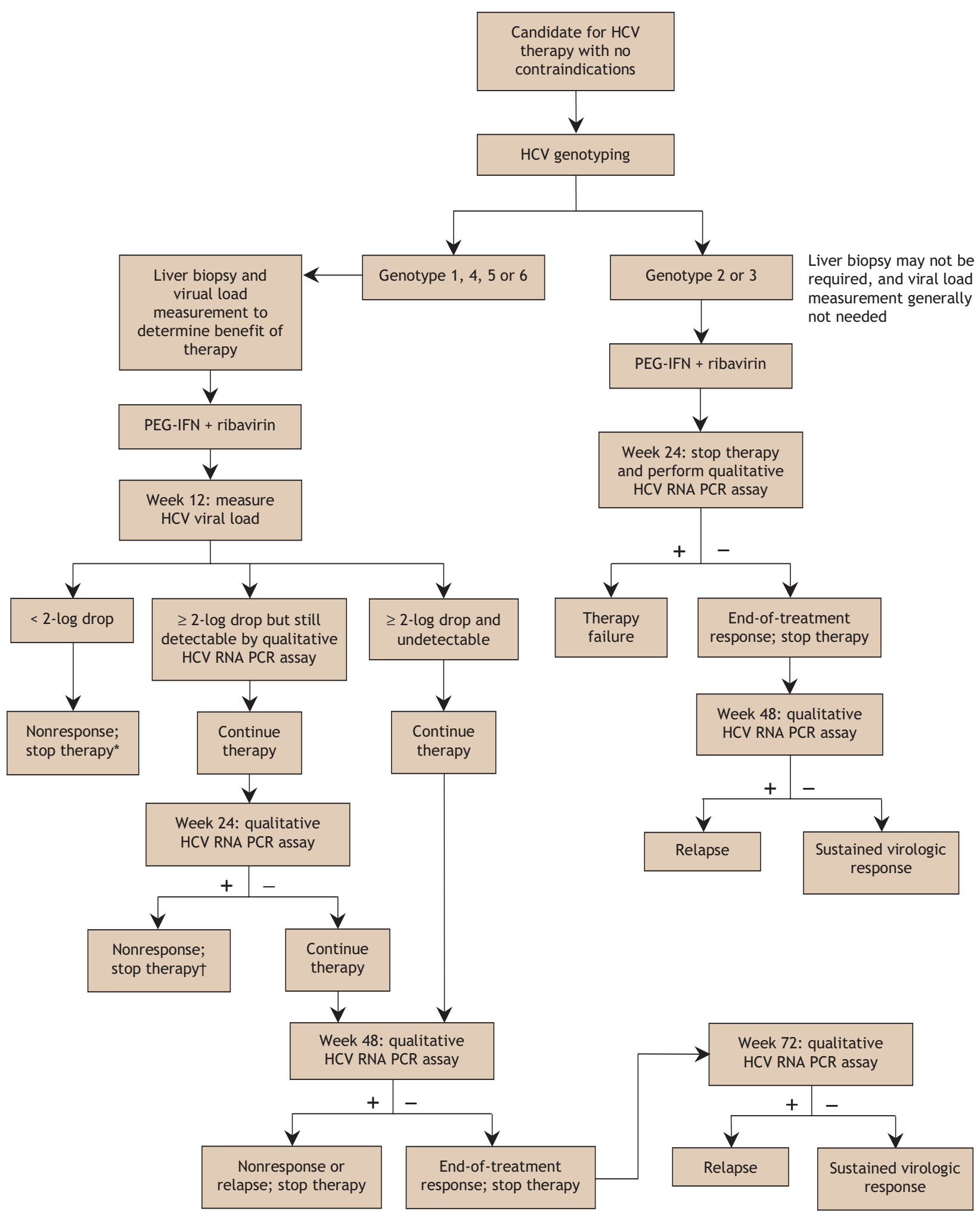

Fig. 3: Algorithm for hepatitis C antiviral therapy. *If the viral load drops by less than 2 logs compared with that at baseline, therapy can be stopped because the likelihood of achieving a sustained virologic response is less than $3 \%{ }^{63,93,96,105,106}+$ Therapy should be stopped if the virus is not cleared at 24 weeks, since sustained virologic response is very unlikely. $.3,107 \mathrm{HCV}=$ hepatitis $\mathrm{C}$ virus, $\mathrm{PEG}$-IFN $=$ pegylated interferon, $\mathrm{PCR}=$ polymerase chain reaction. 
effects arising from antiviral therapy (see Box 3). Online Appendix I, available at www.cmaj.ca/cgi/content/full/cmaj .I030034/DCI, shows the appropriate laboratory investigations during antiviral therapy. Adverse events are more likely with higher medication doses, longer treatment duration and HIV-HCV coinfection. Adverse effects can be sufficiently severe to necessitate discontinuing therapy in up to $17 \%$ of patients taking combination peginterferon-ribavirin therapy. ${ }^{63}$ In particular, ribavirin-induced hemolysis and interferoninduced neutropenia may require dosage adjustments, and hematopoietic growth factors may be used by some experts to treat cytopenias. However, it is unknown whether such growth factors affect treatment outcomes; studies are needed. Patients with depression may benefit from antidepressant and nonpharmacologic therapy. In light of the potential teratogenicity of ribavirin, it is critical that both men and women adhere to strict contraception practices during ribavirin therapy and for 6 months afterward.

Alcohol consumption accelerates the progression of hepatitis C. Avoiding alcohol during therapy is essential because alcohol affects treatment response. ${ }^{63,81,122-126}$ Strict birth control must be followed by both men and women. Interferon has abortifacient effects in animal studies and should not be used during pregnancy. Ribavirin is embryotoxic and teratogenic. It is not known whether interferon or ribavirin is excreted in human milk. Lactating women should not take interferon-ribavirin combination therapy.

\section{HIV-HCV coinfected patients}

HCV and HIV share the same parenteral transmission route. As such, coinfection with both viruses is common. ${ }^{86,127} \mathrm{HCV}$ screening is recommended for all HIV-infected patients. If the patient has a negative anti-HCV test result in the presence of abnormal liver enzyme levels and high hepatitis $\mathrm{C}$ risk factors, qualitative HCV RNA PCR testing should be done. Since the introduction of highly active antiretroviral therapy (HAART), HIV-associated morbidity and mortality have dropped drastically, and HCV-associated liver failure and death have become more prominent in coinfected patients. ${ }^{128}$ HIV accelerates the progression of hepatitis C, especially when the $\mathrm{CD}_{4}$ count is below 200 cells $/ \mathrm{mL}^{86,129-131}$ In the presence of HIV, the response to HCV antiviral therapy is not as favourable (sustained virologic response of $14 \%-38 \%$ for genotype I and $43 \%-73 \%$ for genotype 2 or 3 ) and adverse events are more common (Table 3). ${ }^{118-121}$ HAART has a favourable effect on the course of hepatitis $\mathrm{C}$, but hepatotoxicity from HAART is a challenge. ${ }^{132,133}$ In HIV-infected people, $\mathrm{HCV}$ seropositivity is an independent predictor of HIV progression and mortality. ${ }^{134-138}$ Coinfection increases the rates of perinatal transmission of both viruses. ${ }^{50,129}$

Discussion of the management of HCV infections or HCV-HIV coinfections is complex and beyond the scope of this paper. Consultation with an experienced specialist is recommended, since antiviral therapy is a rapidly changing area. Addiction and mental health comorbidities are important barriers to adherence to treatment and care for some patients. In such circumstances, it is important for primary care providers to enlist the help of colleagues in the fields of social work, addiction or mental health.

\section{Other management issues}

Patients with hepatitis C should be warned about the increased risk of disease progression associated with obesity and moderate or heavy alcohol consumption. NSAIDs should be avoided if possible by patients with liver disease, especially those with cirrhosis, because of the risk of acute renal dys-

Table 3: Summary of results of randomized controlled trials for hepatitis $C$ therapy ${ }^{10,63,95,96,102,108-121}$

\begin{tabular}{|c|c|c|c|c|}
\hline \multirow[b]{2}{*}{ Patient population } & \multicolumn{4}{|c|}{ Therapy; $\%$ of patients } \\
\hline & $\begin{array}{l}\text { Pegylated interferon } \\
+ \text { ribavirin }\end{array}$ & $\begin{array}{c}\text { Standard interferon } \\
+ \text { ribavirin }\end{array}$ & $\begin{array}{l}\text { Pegylated interferon } \\
\text { monotherapy }\end{array}$ & $\begin{array}{l}\text { Standard interferon } \\
\text { monotherapy }\end{array}$ \\
\hline \multicolumn{5}{|l|}{ No HIV coinfection } \\
\hline \multicolumn{5}{|l|}{ Sustained virologic response } \\
\hline Genotype 1 & $42-52$ & $28-36$ & $12-31$ & $2-6$ \\
\hline Genotype 2 or 3 & $76-88$ & $61-79$ & 49 & 28 \\
\hline Genotype 4,5 or 6 & $33-77$ & $26-44$ & 60 & 0 \\
\hline Histologic response & $68-72$ & 69 & $48-63$ & $31-57$ \\
\hline $\begin{array}{l}\text { Therapy discontinued } \\
\text { because of adverse event }\end{array}$ & $3-16$ & $11-13$ & $7-22$ & $6-10$ \\
\hline \multicolumn{5}{|l|}{ HIV coinfection } \\
\hline \multicolumn{5}{|c|}{ Sustained HCV virologic response } \\
\hline Genotype 1 & $14-38$ & $6-7$ & 14 & - \\
\hline Genotype 2 or 3 & $43-73$ & $20-47$ & 36 & - \\
\hline Histologic response & 22 & 15 & - & - \\
\hline $\begin{array}{l}\text { Therapy discontinued } \\
\text { because of adverse event }\end{array}$ & $12-17$ & $12-16$ & 16 & - \\
\hline
\end{tabular}


Box 3: Adverse effects of hepatitis $C$ therapies

Interferon

Common $(\geq 10 \%)$

- Mild bone marrow suppression (anemia, leukopenia, thrombocytopenia)

- Depression

- Insomnia

- Fatigue and irritability

- Weight loss, anorexia

- Fever, myalgia, headaches and flu-like symptoms

- Alopecia

- Skin irritation at injection site

- Nausea, vomiting and diarrhea

Occasional (2\%-9\%)

- Retinopathy (usually not clinically significant)

- Exacerbation of autoimmune condition (e.g., autoimmune hepatitis, autoimmune thyroiditis, rheumatoid arthritis, psoriasis)

- Congestive heart failure and arrhythmias

Rare $(\leq 1 \%)$

- Severe bone marrow suppression

- Seizures

- Tinnitus and hearing loss

- Hyperglycemia

- Renal failure

- Pneumonitis

Ribavirin

Common ( $\geq 10 \%)$

- Hemolytic anemia (dose dependent)

- Fatigue

- Rash and pruritis

- Nasal stuffiness

- Cough

function. For analgesia, small doses of ASA $(<2 \mathrm{~g} / \mathrm{d})$ are vastly preferable to NSAIDs in patients with liver disease. Immunization against hepatitis $A$ and $B$ virus infection if there is no evidence of past infection or immunity ${ }^{93,139-142}$ can prevent future assaults on the liver from these infections.

It is unnecessary to screen for HCV-associated hepatocellular carcinoma in the absence of cirrhosis because it is rare that they do not occur together. There have been no randomized controlled trials assessing the value of screening HCVinfected patients for hepatocellular carcinoma. Screening with alpha fetoprotein levels has been shown to range from insensitive $(<20 \%)$ to moderately sensitive $(>80 \%)$ as the cut-off point decreases from $400 \mu \mathrm{g} / \mathrm{L}$ to $10 \mu \mathrm{g} / \mathrm{L}$, at the cost of dramatically decreasing specificity. ${ }^{143-150}$ Screening with ultrasound has varying sensitivities but generally high specificity (> 90\%). ${ }^{146,147,151,152}$ Combining ultrasound with tests for alpha fetoprotein levels may have better sensitivity than either modality alone. ${ }^{147}$ Results from a cohort study suggest that such combination screening may detect hepatocellular carci- noma at an earlier, resectable stage. ${ }^{153}$ However, some experts suggest screening only with periodic ultrasounds, since adding a test for alpha fetoprotein levels only marginally improves sensitivity and adds many false-positive test results that need to be intensively investigated. ${ }^{150}$ Screening for hepatocellular carcinoma after cirrhosis develops may result in earlier detection, ${ }^{58,63,66,154}$ but whether such screening improves mortality outcomes awaits further prospective randomized controlled trials.

\section{Prevention and counselling}

Prevention is an important component of care and should target both HCV-infected people and those at risk but not yet infected. Uninfected people can be counselled to prevent acquiring the virus (see Box I). Those who are infected can avoid risky practices associated with transmission.

Counselling recommendations include:

- Report newly diagnosed cases of HCV infection to the local public health department in accordance with provincial and territorial requirements.

- Infected patients should not donate blood, organs, tissues or semen, and they should not share sharp items potentially contaminated with blood (e.g., razors, nail clippers, scissors, toothbrushes).

- Infected patients should inform their sexual partners and practise safer sex if they are not in a monogamous, longterm relationship. Those in a monogamous, long-term relationship do not need to change their sexual practices, but they should be informed of the very low risk of sexual transmission except with the moderate-risk sexual activities listed in Box I. Consider testing the patient's partner for HCV infection.

- Counsel and test HCV-infected patients for HIV and hepatitis B infection.

- Patients should limit their alcohol intake to fewer than 4 drinks per week. The threshold amount of alcohol in HCVinfected patients that increases the fibrosis progression rate remains unclear, but it is almost certainly greater than one daily drink. Therefore, it seems reasonable to set a limit to about half that amount.

- Do not track alanine transferase values. HCV infection causes fluctuations, sometimes marked, in serum levels. They do not have any prognostic significance, and some patients tend to worry unduly about values that are higher than previous ones. We recommend that patients not track these levels.

- Patients should avoid other hepatotoxins, including many herbal products such as kava (a comprehensive list of hepatotoxins is available online as Appendix 2 at www.cmaj. ca/cgi/content/full/cmaj.I030034/DCI).

- No alternative or complementary remedy has been shown to affect HCV liver disease or HCV itself. This includes the "liver herb" silymarin (milk thistle). Therefore, patients should avoid these.

- Hepatitis C can now be treated in many patients. Even without treatment, most patients with chronic infection do not die of liver disease, and most live a normal lifespan. 


\section{Conclusions}

Although many patients are unaware of their HCV infection status, primary care physicians are in a unique position to help identify, counsel, refer and monitor patients at risk of HCV infection and its associated infections and complications. Ongoing awareness by patients and primary care physicians of factors that promote HCV transmission and disease progression may reduce the burden of disease and identify more patients who would benefit from effective therapy.

\section{This article has been peer reviewed.}

From the Public Health Agency of Canada and the University of Ottawa, Ottawa, and the University of Toronto, Toronto, Ont. (Wong), and from the Department of Medicine, Liver Unit, University of Calgary, Calgary, Alta. (Lee)

Competing interests: None declared for Tom Wong. Samuel Lee has been a paid consultant with Roche and Genentech and has received research grants from Roche, Schering-Plough, Migenix, Idenix, Gilead and Novartis as well as speaker fees and educational grants from Roche and Axcan.

Contributors: Tom Wong conceived and wrote the article, and Samuel Lee made a substantial contribution to its content. Both authors critically revised the article for important intellectual content and gave final approval of the version to be published.

\section{REFERENCES}

I. Choo QL, Kuo G, Weiner AJ, et al. Isolation of a cDNA clone derived from a bloodborne non-A, non-B viral hepatitis genome. Science I989;244:359-62.

2. Andonov A, Chaudhary RK. Genotyping of Canadian hepatitis $C$ virus isolates by PCR. J Clin Microbiol I994;32:203I-4.

3. Bernier L, Willems B, Delage G, et al. Identification of numerous hepatitis C virus genotypes in Montreal, Canada. J Clin Microbiol ig96;34:2815-8.

4. Murphy DG, Willems B, Delage G, et al. Hepatitis C virus genotypes in patients and blood donors - Quebec. Can Commun Dis Rep I995;21:129-32.

5. Shepard CW, Finelli L, Alter MJ. Global epidemiology of hepatitis C virus infection. Lancet Infect Dis 2005;5:558-67.

6. WHO. Hepatitis C — global prevalence (update). Wkly Epidemiol Rec I999;74:425-7.

7. Public Health Agency of Canada. A study to characterize the epidemiology of hepatitis C infection in Canada, 2002. Final report. 2004. Ottawa: Health Canada; 2004

8. Zou S, Tepper M, Giulivi A. Current status of hepatitis C in Canada. Can J Public Health 2000;9I(Suppl I):Sio-I6.

9. Myers RP, Hilsden RJ, Lee SS. Historical features are poor predictors of liver fibrosis in Canadian patients with chronic hepatitis C. J Viral Hepat 200I;8:249-55

ro. Lindsay $\mathrm{KL}$, Trepo $\mathrm{C}$, Heintges $\mathrm{T}$, et al. A randomized, double-blind trial comparing pegylated interferon alfa- $2 \mathrm{~b}$ to interferon alfa-2b as initial treatment for chronic hepatitis C. Hepatology 200I;34:395-403.

II. Stratton E, Sweet L, Latorraca-Walsh A, et al. Hepatitis C in Prince Edward Island: a descriptive review of reported cases, 1990-1995. Can J Public Health 1997;88:9I-4.

12. Ahmad K. Pakistan:a cirrhotic state? Lancet 2004;364:1843-4.

I3. Chen TZ, Wu JC, Yen FS, et al. Injection with nondisposable needles as an important route for transmission of acute community-acquired hepatitis $\mathrm{C}$ virus infection in Taiwan. JMed Virol I995;46:247-5I.

I4. Chlabicz S, Grzeszczuk A, Prokopowicz D. Medical procedures and the risk of iatrogenic hepatitis $\mathrm{C}$ infection: case-controlled study in north-eastern Poland. $J$ Hosp Infect 2004;58:204-9.

I5. Comandini UV, Tossini G, Longo MA, et al. Sporadic hepatitis C virus infection: a case-control study of transmission routes in a selected hospital sample of the general population in Italy. Scand J Infect Dis I998;30:II-5.

I6. Frank C, Mohamed MK, Strickland GT, et al. The role of parenteral antischistosomal therapy in the spread of hepatitis C virus in Egypt. Lancet 2000;355:887-9I.

17. Habib M, Mohamed MK, bdel-Aziz F, et al. Hepatitis C virus infection in a community in the Nile Delta: risk factors for seropositivity. Hepatology 200I Jan;33(I): 248-53.

I8. Hauri AM, Armstrong GL, Hutin YJ. The global burden of disease attributable to contaminated injections given in health care settings. Int J STD AIDS 2004;15:7-I6.

I9. Hutin YJ, Hauri AM, Armstrong GL. Use of injections in healthcare settings worldwide, 2000: literature review and regional estimates. BMJ 2003;327:1075.

20. Kane A, Lloyd J, Zaffran M, et al. Transmission of hepatitis B, hepatitis C and human immunodeficiency viruses through unsafe injections in the developing world: model-based regional estimates. Bull World Health Organ 1999;77:80I-7.

2I. Khan AJ, Luby SP, Fikree F, et al. Unsafe injections and the transmission of hepatitis B and C in a periurban community in Pakistan. Bull World Health Organ 2000; 78:956-63.
22. Luby SP, Qamruddin K, Shah AA, et al. The relationship between therapeutic injections and high prevalence of hepatitis $\mathrm{C}$ infection in Hafizabad, Pakistan. Epidemiol Infect I997; I19:349-56.

23. Maio G, d'Argenio P, Stroffolini T, et al. Hepatitis C virus infection and alanine transaminase levels in the general population: a survey in a southern Italian town. $J$ Hepatol 2000;33:116-20.

24. Mele A, Spada E, Sagliocca L, et al. Risk of parenterally transmitted hepatitis following exposure to surgery or other invasive procedures: results from the hepatitis surveillance system in Italy. J Hepatol 2001;35:284-9.

25. Mizokami M, Tanaka Y. Tracing the evolution of hepatitis C virus in the United States, Japan, and Egypt by using the molecular clock. Clin Gastroenterol Hepatol 2005;3(Suppl 2):S82-5.

26. Montella M, Crispo A, Grimaldi M, et al. Assessment of iatrogenic transmission of HCV in Southern Italy: was the cause the Salk polio vaccination? J Med Virol 2003 70:49-50.

27. Pasha O, Luby SP, Khan AJ, et al. Household members of hepatitis C virus-infected people in Hafizabad, Pakistan: infection by injections from health care providers. Epidemiol Infect 1999;123:515-8.

28. Simonsen L, Kane A, Lloyd J, et al. Unsafe injections in the developing world and transmission of bloodborne pathogens: a review. Bull World Health Organ 1999; 77:789-80o.

29. Singh S, Kumar J, Singh R, et al. Hepatitis B and C viral infections in Indian kalaazar patients receiving injectable anti-leishmanial drugs: a community-based study. Int J Infect Dis 2000;4:203-8.

30. Sun CA, Chen HC, Lu SN, et al. Persistent hyperendemicity of hepatitis C virus infection in Taiwan: the important role of iatrogenic risk factors. J Med Virol 200I; 65:30-4.

3r. Tanaka Y, Hanada K, Orito E, et al. Molecular evolutionary analyses implicate injection treatment for schistosomiasis in the initial hepatitis $\mathrm{C}$ epidemics in Japan. Hepatol 2005;42:47-53.

32. Wasley A, Alter MJ. Epidemiology of hepatitis C: geographic differences and temporal trends. Semin Liver Dis 2000;20:I-I6.

33. Miller MA, Pisani E. The cost of unsafe injections. Bull World Health Organ I999; 77:808-II

34. Centers for Disease Control. Hepatitis C Slide Set. 2005

35. Donahue JG, Munoz A, Ness PM, et al. The declining risk of post-transfusion hepatitis C virus infection. N Engl J Med I992;327:369-73.

36. Zou S, Forrester L, Giulivi A. Hepatitis C update. Can J Public Health 2003;94:127-9.

37. Infectious Diseases and Immunization Committee CPS. Transfusion and risk of infection in Canada: Update 2005. J Paediatr Child Health 2005;IO:I49-53

38. Boucher M, Gruslin A; Members of the Infectious Disease Committee of SOGC. SOGC Clinical Practice Guidelines: The reproductive care of women living with hepatitis C infection. J Soc Ob Gyn Can 2000;22:820-44.

39. Alary M, Joly JR, Vincelette J, et al. Lack of evidence of sexual transmission of hepatitis $\mathrm{C}$ virus in a prospective cohort study of men who have sex with men. Am J Public Health 2005;95:502-5.

40. Nakashima K, Kashiwagi S, Hayashi J, et al. Sexual transmission of hepatitis C virus among female prostitutes and patients with sexually transmitted diseases in Fukuoka, Kyushu, Japan. Am J Epidemiol I992;136:II32-7.

4I. Van Doornum GJ, Hooykaas C, Cuypers MT, et al. Prevalence of hepatitis C virus infections among heterosexuals with multiple partners. J Med Virol I99I;35:22-7.

42. Petersen EE, Clemens R, Bock HL, et al. Hepatitis B and C in heterosexual patients with various sexually transmitted diseases. Infection I992;20:128-31.

43. Eyster ME, Alter HJ, Aledort LM, et al. Heterosexual co-transmission of hepatitis C virus (HCV) and human immunodeficiency virus (HIV). Ann Intern Med I99I;II5: $764-8$.

44. Brettler DB, Mannucci PM, Gringeri A, et al. The low risk of hepatitis C virus transmission among sexual partners of hepatitis C-infected hemophilic males: an international, multicenter study. Blood ig92;80:540-3.

45. Gordon SC, Patel AH, Kulesza GW, et al. Lack of evidence for the heterosexual transmission of hepatitis C. Am J Gastroenterol I992;87:I849-5I.

46. Ruys TA, den Hollander JG, Beld MG, et al. [Sexual transmission of hepatitis C in homosexual men]. Ned Tijdschr Geneeskd 2004;I48:2309-I2.

47. Ghosn J, Pierre-Francois S, Thibault V, et al. Acute hepatitis C in HIV-infected men who have sex with men. HIV Med 2004;5:303-6.

48. van Agtmael MA, Perenboom RM. Two HIV-positive men with anorectal lymphogranuloma venereum and hepatitis C: emerging sexually transmitted diseases. Ned Tijdschr Geneeskd 2004; I48:2547-50.

49. Fletcher S. Sexual transmission of hepatitis C and early intervention. J Assoc Nurses AIDS Care 2003; I4(5 Suppl):87S-94S.

50. Zanetti AR, Tanzi E, Paccagnini S, et al. Mother-to-infant transmission of hepatitis C virus. Lombardy Study Group on Vertical HCV Transmission. Lancet 1995;345: 289-9I.

5I. Manzini P, Saracco G, Cerchier A, et al. Human immunodeficiency virus infection as risk factor for mother-to-child hepatitis $\mathrm{C}$ virus transmission; persistence of anti-hepatitis $\mathrm{C}$ virus in children is associated with the mother's anti-hepatitis $\mathrm{C}$ virus immunoblotting pattern. Hepatology 1995;21:328-32.

52. Roberts EA, Yeung L. Maternal-infant transmission of hepatitis C virus infection. Hepatology 2002;36(Suppl I):Sio6-13.

53. Lin $\mathrm{HH}$, Kao JH, Hsu HY, et al. Absence of infection in breast-fed infants born to hepatitis C virus-infected mothers. J Pediatr I995;I26:589-9I.

54. Seeff LB, Wright EC, Zimmerman HI, et al. Type B hepatitis after needle-stick exposure: prevention with hepatitis B immune globulin. Final report of the Veterans Administration Cooperative Study. Ann Intern Med 1978;88:285-93. 
55. Kiyosawa K, Sodeyama T, Tanaka E, et al. Hepatitis C in hospital employees with needlestick injuries. Ann Intern Med 1991;II5:367-9.

56. Mitsui T, Iwano K, Masuko K, et al. Hepatitis $\mathrm{C}$ virus infection in medical personnel after needlestick accident. Hepatology 1992;16:IIo9-I4.

57. Pereira BJ, Milford EL, Kirkman RL, et al. Transmission of hepatitis C virus by organ transplantation. N Engl J Med I991;325:454-60.

58. Stuyver L, Claeys H, Wyseur A, et al. Hepatitis $\mathrm{C}$ virus in a hemodialysis unit: molecular evidence for nosocomial transmission. Kidney Int 1996;49:889-95.

59. Shimokura GH, Gully PR. Risk of hepatitis C virus infection through tattooing and other skin piercing services. Can Infect Dis 1995;6:235-8.

6o. Ko YC, Ho MS, Chiang TA, et al. Tattooing as a risk of hepatitis $\mathrm{C}$ virus infection. $J$ Med Virol 1992;38:288-9I.

6r. Conry-Cantilena C, VanRaden M, Gibble J, et al. Routes of infection, viremia, and liver disease in blood donors found to have hepatitis C virus infection. $N$ Engl $J$ Med I996;334:I69I-6.

62. Koblin BA, Factor SH, Wu Y, et al. Hepatitis $\mathrm{C}$ virus infection among noninjecting drug users in New York City. J Med Virol 2003;70:387-90.

63. NIH Expert Panel. NIH Consensus Statement on Management of Hepatitis C 2002. NIH Consens State Sci Statements 2002;19:I-46.

64. Health Canada and The College of Family Physicians of Canada. Physicians' Desk Reference - Primary care management of hepatitis C. Pamphlet. Ottawa; 2002.

65. Koretz RL, Brezina M, Polito AJ, et al. Non-A, non-B posttransfusion hepatitis: comparing $\mathrm{C}$ and non-C hepatitis. Hepatology 1993; $17: 36 \mathrm{I}-5$.

66. Aach RD, Stevens CE, Hollinger FB, et al. Hepatitis C virus infection in post-transfusion hepatitis. An analysis with first- and second-generation assays. $N$ Engl $J$ Med I991;325:1325-9.

67. Alter HJ, Purcell RH, Shih JW, et al. Detection of antibody to hepatitis C virus in prospectively followed transfusion recipients with acute and chronic non-A, non-B hepatitis. N Engl J Med I989;321:I494-500.

68. Seeff LB. Natural history of chronic hepatitis C. Hepatology 2002;36(Suppl I):S35-46.

69. Koretz RL, Abbey H, Coleman E, et al. Non-A, non-B post-transfusion hepatitis Looking back in the second decade. Ann Intern Med I993;II9:IIO-5.

70. Recommendations for prevention and control of hepatitis $\mathrm{C}$ virus (HCV) infection and HCV-related chronic disease. Centers for Disease Control and Prevention. MMWR Recomm Rep 1998;47(RR-19):I-39.

7I. Gumber SC, Chopra S. Hepatitis C: a multifaceted disease. Review of extrahepatic manifestations. Ann Intern Med 1995;123:615-20.

72. DeCastro M, Sanchez J, Herrera JF, et al. Hepatitis C virus antibodies and liver disease in patients with porphyria cutanea tarda. Hepatology 1993;17:551-7.

73. Herrero C, Vicente A, Bruguera M, et al. Is hepatitis C virus infection a trigger of porphyria cutanea tarda? Lancet 1993;341:788-9.

74. Fargion S, Piperno A, Cappellini MD, et al. Hepatitis C virus and porphyria cutanea tarda: evidence of a strong association. Hepatology 1992; 6 :1322-6.

75. Misiani R, Bellavita P, Fenili D, et al. Hepatitis C virus infection in patients with essential mixed cryoglobulinemia. Ann Intern Med I992;117:573-7.

76. Agnello V, Chung RT, Kaplan LM. A role for hepatitis C virus infection in type II cryoglobulinemia. N Engl J Med I992;327:I490-5

77. Johnson RJ, Gretch DR, Yamabe H, et al. Membranoproliferative glomerulonephritis associated with hepatitis C virus infection. NEngI IMed I993;328:465-70.

78. Ferri C, Caracciolo F, Zignego AL, et al. Hepatitis C virus infection in patients with non-Hodgkin's lymphoma. Br J Haematol I994;88:392-4

79. Pozzato G, Mazzaro C, Crovatto M, et al. Low-grade malignant lymphoma, hepatitis C virus infection, and mixed cryoglobulinemia. Blood I994;84:3047-53.

8o. Fireman M, Indest DW, Blackwell A, et al. Addressing tri-morbidity (hepatitis C, psychiatric disorders, and substance use): the importance of routine mental health screening as a component of a comanagement model of care. Clin Infect Dis 2005; 40(Suppl 5):S286-9I.

8I. Corrao G, Arico S. Independent and combined action of hepatitis C virus infection and alcohol consumption on the risk of symptomatic liver cirrhosis. Hepatology 1998;27:914-9.

82. Schiff ER. Hepatitis C and alcohol. Hepatology 1997;26(Suppl I):39S-42S

83. Benvegnu L, Fattovich G, Noventa F, et al. Concurrent hepatitis B and C virus infection and risk of hepatocellular carcinoma in cirrhosis. A prospective study. Cancer 1994;74:2442-8

84. Thomas DL, Shih JW, Alter HJ, et al. Effect of human immunodeficiency virus on hepatitis C virus infection among injecting drug users. Infect Dis 1996;174:690-5.

85. Collier J, Heathcote J. Hepatitis C viral infection in the immunosuppressed patient. Hepatology $1998 ; 27: 2-6$.

86. Eyster ME, Diamondstone LS, Lien JM, et al. Natural history of hepatitis C virus infection in multitransfused hemophiliacs: effect of coinfection with human immunodeficiency virus. The Multicenter Hemophilia Cohort Study. J Acquir Immune Defic Syndr 1993;6:602-Io.

87. Kenny-Walsh E. Clinical outcomes after hepatitis C infection from contaminated anti-D immune globulin. Irish Hepatology Research Group. N Engl J Med I999; 340:1228-33

88. Gully PR, Tepper ML. Hepatitis C. CMAJ I997;I56:I427-30.

89. Taylor MC, Greig PD, Detsky AS, et al. Factors associated with the high cost of liver transplantation in adults. Can J Surg 2002;45:425-34.

9o. Chou R, Clark EC, Helfand M. Screening for hepatitis C virus infection: a review of the evidence for the U.S. Preventive Services Task Force. Ann Intern Med 2004; $140: 465-79$.

9I. Calonge N, Randhawa G. The meaning of the U.S. Preventive Services Task Force grade I recommendation: screening for hepatitis C virus infection. Ann Intern Med 2004;141:718-9.
92. Alter MJ, Seeff LB, Bacon BR, et al. Testing for hepatitis C virus infection should be routine for persons at increased risk for infection. Ann Intern Med 2004;141:715-7.

93. Sherman M, Bain V, Villeneuve JP, et al. The management of chronic viral hepatitis: a Canadian consensus conference 2004. Can J Gastroenterol 2004;18:715-28.

94. Lee SS. Histological response to interferon alfa-based therapies in hepatitis C. Semin Liver Dis 2004;24(Suppl 2):55-60.

95. Manns MP, McHutchison JG, Gordon SC, et al. Peginterferon alfa-2b plus ribavirin compared with interferon alfa-2b plus ribavirin for initial treatment of chronic hepatitis C: a randomised trial. Lancet 2001;358:958-65.

96. Fried MW, Shiffman ML, Reddy KR, et al. Peginterferon alfa-2a plus ribavirin for chronic hepatitis C virus infection. N Engl J Med 2002;347:975-82.

97. International Interferon-alpha Hepatocellular Carcinoma Study Group. Effect of interferon-alpha on progression of cirrhosis to hepatocellular carcinoma: a retrospective cohort study. Lancet 1998;351:1535-9.

98. Alter MJ, Kuhnert WL, Finelli L, et al. Guidelines for laboratory testing and result reporting of antibody to hepatitis $\mathrm{C}$ virus. Centers for Disease Control and Prevention. MMWR Recomm Rep 2003;52(RR-3):I-I3, I5.

99. Courouce AM, Le MN, Girault A, et al. Anti-hepatitis C virus (anti-HCV) seroconversion in patients undergoing hemodialysis: comparison of second- and thirdgeneration anti-HCV assays. Transfusion 1994;34:790-5.

Ioo. Gutfreund KS, Bain VG. Chronic viral hepatitis C: management update. CMAJ 2000;162:827-33.

IoI. Strader DB, Wright T, Thomas DL, et al. Diagnosis, management, and treatment of hepatitis C. Hepatology 2004:39:II47-7I

I02. Derbala M, Amer A, Bener A, et al. Pegylated interferon-alpha 2b-ribavirin combination in Egyptian patients with genotype 4 chronic hepatitis. J Viral Hepat 2005;I2:380-5.

I03. Kamal SM, El Tawil AA, Nakano T, et al. Peginterferon \{alpha\}-2b and ribavirin therapy in chronic hepatitis C genotype 4: impact of treatment duration and viral kinetics on sustained virological response. Gut 2005:54:858-66.

I04. Abdo AA, Lee SS. Management of hepatitis C virus genotype 4. J Gastroenterol Hepatol 2004;19:1233-9.

105. Davis GL, Wong JB, McHutchison JG, et al. Early virologic response to treatment with peginterferon alfa-2b plus ribavirin in patients with chronic hepatitis $\mathrm{C}$. Hepatology 2003;38:645-52

106. Lee SS. Review article: indicators and predictors of response to anti-viral therapy in chronic hepatitis C. Aliment Pharmacol Ther 2003;17:6II-2I

107. Marcellin P, Boyer N, Gervais A, et al. Long-term histologic improvement and loss of detectable intrahepatic HCV RNA in patients with chronic hepatitis $C$ and sustained response to interferon-alpha therapy. Ann Intern Med I997;127:875-8I.

Io8. Hadziyannis SJ, Sette H Jr, Morgan TR, et al. Peginterferon-alphaza and ribavirin combination therapy in chronic hepatitis $\mathrm{C}$ : a randomized study of treatment duration and ribavirin dose. Ann Intern Med 2004;140:346-55.

Iog. Mangia A, Santoro R, Minerva N, et al. Peginterferon alfa-2b and ribavirin for 12 vs. 24 weeks in HCV genotype 2 or 3. N Engl J Med 2005;352:2609-17.

IIo. Mangia A, Ricci GL, Persico M, et al. A randomized controlled trial of pegylated interferon alpha-2a (40 KD) or interferon alpha-2a plus ribavirin and amantadine vs interferon alpha-2a and ribavirin in treatment-naive patients with chronic hepatitis C. J Viral Hepat 2005;12:292-9.

III. Di Bisceglie AM, Hoofnagle JH. Optimal therapy of hepatitis C. Hepatology 2002;36(Suppl I):SI2I-7.

II2. Chander G, Sulkowski MS, Jenckes MW, et al. Treatment of chronic hepatitis C: a systematic review. Hepatology 2002;36(Suppl I):Si35-44.

II3. Heathcote EJ, Shiffman ML, Cooksley WG, et al. Peginterferon alfa-2a in patients with chronic hepatitis C and cirrhosis. N EngI J Med 2000;343:1673-80.

II4. Zeuzem S, Feinman SV, Rasenack J, et al. Peginterferon alfa-2a in patients with chronic hepatitis C. NEngl J Med 2000;343:1666-72.

II5. Reddy KR, Wright TL, Pockros PJ, et al. Efficacy and safety of pegylated (40-kd) interferon alpha-2a compared with interferon alpha-2a in noncirrhotic patients with chronic hepatitis C. Hepatology 200I;33:433-8.

II6. Poynard T, Marcellin P, Lee SS, et al. Randomised trial of interferon alphazb plus ribavirin for 48 weeks or for 24 weeks versus interferon alphazb plus placebo for 48 weeks for treatment of chronic infection with hepatitis C virus. International Hepatitis Interventional Therapy Group (IHIT). Lancet 1998;352:I426-32.

II7. McHutchison JG, Gordon SC, SchiffeR, et al. Interferon alfa-2b alone or in combination with ribavirin as initial treatment for chronic hepatitis C. Hepatitis Interventional Therapy Group. N Engl J Med I998;339:1485-92.

II8. Torriani FJ, Rodriguez-Torres M, Rockstroh JK, et al. Peginterferon Alfa-2a plus ribavirin for chronic hepatitis C virus infection in HIV-infected patients. $N$ Engl Med 2004;351:438-50.

IIg. Carrat F, Bani-Sadr F, Pol S, et al. Pegylated interferon alfa- $2 \mathrm{~b}$ vs standard interferon alfa-2b, plus ribavirin, for chronic hepatitis $\mathrm{C}$ in HIV-infected patients: a randomized controlled trial. JAMA 2004;292:2839-48.

I20. Perez-Olmeda $M$, Soriano V, Asensi V, et al. Treatment of chronic hepatitis $C$ in HIV-infected patients with interferon alpha-2b plus ribavirin. AIDS Res Hum Retroviruses 2003;19:1083-9.

I2I. Moreno L, Quereda C, Moreno A, et al. Pegylated interferon alphazb plus ribavirin for the treatment of chronic hepatitis C in HIV-infected patients. AIDS 2004;18:67-73.

I22. Wiley TE, McCarthy M, Breidi L, et al. Impact of alcohol on the histological and clinical progression of hepatitis C infection. Hepatology 1998;28:805-9.

I23. Bellentani S, Pozzato G, Saccoccio G, et al. Clinical course and risk factors of hepatitis $\mathrm{C}$ virus related liver disease in the general population: report from the Dionysos study. Gut 1999;44:874-80.

I24. Noda K, Yoshihara H, Suzuki K, et al. Progression of type C chronic hepatitis to liver cirrhosis and hepatocellular carcinoma-its relationship to alcohol drinking 
and the age of transfusion. Alcohol Clin Exp Res i996;20(I Suppl):95A-10oA.

I25. Pessione F, Degos F, Marcellin P, et al. Effect of alcohol consumption on serum hepatitis C virus RNA and histological lesions in chronic hepatitis C. Hepatology I998;27:1717-22.

I26. Romero-Gomez M, Grande L, Nogales MC, et al. Intrahepatic hepatitis C virus replication is increased in patients with regular alcohol consumption. Dig Liver Dis 2001;33:698-702.

I27. Jayaraman GC, Bush KR, Lee B, et al. Magnitude and Determinants of First-Time and Repeat Testing Among Individuals With Newly Diagnosed HIV Infection Between 2000 and 2001 in Alberta, Canada: Results From Population-Based Laboratory Surveillance. J Acquir Immune Defic Syndr 2004;37:I65I-6.

I28. Macias J, Melguizo I, Fernandez-Rivera FJ, et al. Mortality due to liver failure and impact on survival of hepatitis virus infections in HIV-infected patients receiving potent antiretroviral therapy. Eur J Clin Microbiol Infect Dis 2002;21:775-8I.

I29. Rockstroh JK, Spengler U. HIV and hepatitis C virus co-infection. Lancet Infect Dis 2004;4:437-44.

I30. Graham CS, Baden LR, Yu E, et al. Influence of human immunodeficiency virus infection on the course of hepatitis C virus infection: a meta-analysis. Clin Infect Dis 2001;33:562-9.

I3I. Telfer P, Sabin C, Devereux H, et al. The progression of HCV-associated liver disease in a cohort of haemophilic patients. BrJ Haematol $1994 ; 87: 555^{-6} \mathrm{I}$.

132. Qurishi N, Kreuzberg C, Luchters G, et al. Effect of antiretroviral therapy on liver related mortality in patients with HIV and hepatitis C virus coinfection. Lancet 2003;362:I708-I3.

133. Benhamou Y, Di M, V, Bochet M, et al. Factors affecting liver fibrosis in human immunodeficiency virus-and hepatitis $\mathrm{C}$ virus-coinfected patients: impact of protease inhibitor therapy. Hepatology 200I Aug;34(2):283-7.

134. Braitstein P, Yip B, Montessori V, et al. Effect of serostatus for hepatitis C virus on mortality among antiretrovirally naive HIV-positive patients. CMAJ 2005;173:I60-4.

I35. Greub G, Ledergerber B, Battegay $M$, et al. Clinical progression, survival, and immune recovery during antiretroviral therapy in patients with HIV-I and hepatitis $\mathrm{C}$ virus coinfection: the Swiss HIV Cohort Study. Lancet 2000;356:1800-5.

I36. Daar ES, Lynn H, Donfield S, et al. Hepatitis C virus load is associated with human immunodeficiency virus type I disease progression in hemophiliacs. J Infect Dis 200I; I83:589-95

137. Klein MB, Lalonde RG, Suissa $S$. The impact of hepatitis $C$ virus coinfection on HIV progression before and after highly active antiretroviral therapy. J Acquir Immune Defic Syndr 2003;33:365-72.

I38. Backus LI, Phillips BR, Boothroyd DB, et al. Effects of hepatitis C virus coinfection on survival in veterans with HIV treated with highly active antiretroviral therapy. $J$ Acquir Immune Defic Syndr 2005;39:613-9.

I39. Akriviadis EA, Redeker AG. Fulminant hepatitis A in intravenous drug users with chronic liver disease. Ann Intern Med I989;1 10:838-9.

I40. Prevention of hepatitis A through active or passive immunization: Recommendations of the Advisory Committee on Immunization Practices (ACIP). MMWR Recomm Rep I999;48(RR-I2):I-37.
I4I. Health Canada. Canadian Immunization Guide Sixth Edition. Ottawa: 2002.

I42. Vento S, Garofano T, Renzini C, et al. Fulminant hepatitis associated with hepatitis A virus superinfection in patients with chronic hepatitis C. N Engl J Med I998;338: 286-9o.

I43. Cottone $M$, Turri $M$, Caltagirone $M$, et al. Screening for hepatocellular carcinoma in patients with Child's A cirrhosis: an 8-year prospective study by ultrasound and alphafetoprotein. J Hepatol I994;21:1029-34.

I44. Larcos G, Sorokopud H, Berry G, et al. Sonographic screening for hepatocellular carcinoma in patients with chronic hepatitis or cirrhosis: an evaluation. AJR Am I Roentgenol 1998;171:433-5.

I45. Tong MJ, Blatt LM, Kao VW. Surveillance for hepatocellular carcinoma in patients with chronic viral hepatitis in the United States of America. J Gastroenterol Hepatol 200I; $6: 553-9$.

I46. Izzo F, Cremona F, Delrio P, et al. Soluble interleukin-2 receptor levels in hepatocellular cancer: a more sensitive marker than alfa fetoprotein. Ann Surg Oncol I999;6:178-85.

I47. Izzo F, Cremona F, Ruffolo F, et al. Outcome of 67 patients with hepatocellular cancer detected during screening of II 25 patients with chronic hepatitis. Ann Surg I998;227:513-8.

I48. Trevisani F, D'Intino PE, Caraceni P, et al. Etiologic factors and clinical presentation of hepatocellular carcinoma. Differences between cirrhotic and noncirrhotic Italian patients. Cancer 1995;75:2220-32.

I49. Ishii M, Gama H, Chida N, et al. Simultaneous measurements of serum alpha-fetoprotein and protein induced by vitamin $\mathrm{K}$ absence for detecting hepatocellular carcinoma. South Tohoku District Study Group. Am J Gastroenterol 2000;95:1036-40.

I50. Sherman M. Screening for hepatocellular carcinoma. Best Pract Res Clin Gastroenterol 2005;I9:IOI-I8.

I5I. Colombo M, de FR, Del NE, et al. Hepatocellular carcinoma in Italian patients with cirrhosis. NEngl J Med I99I Sep 5;325(I0):675-80.

152. Kasahara A, Hayashi N, Mochizuki K, et al. Risk factors for hepatocellular carcinoma and its incidence after interferon treatment in patients with chronic hepatitis C. Osaka Liver Disease Study Group. Hepatology 1998;27:1394-402.

153. Solmi L, Primerano AM, Gandolfi L. Ultrasound follow-up of patients at risk for hepatocellular carcinoma: results of a prospective study on 360 cases. Am J Gastroenterol I996;91:II89-94.

I54. Gebo KA, Chander G, Jenckes MW, et al. Screening tests for hepatocellular carcinoma in patients with chronic hepatitis C: a systematic review. Hepatology 2002; 36(Suppl I):S84-92.

Correspondence to: Dr. Tom Wong, Centre for Infectious Disease Prevention and Control, Public Health Agency of Canada, Jeanne Mance Bldg., Room 647B, Tunney's Pasture, PLigo6B, Ottawa ON KIA oKg; tom_wong@hc-sc.gc.ca

\section{AMA/CMA International Conference on Physician Health}

Fairmont Château Laurier

Ottawa, Ontario, Canada 30 November-2 December 2006

\section{$\checkmark$ Mark your calendar now ... and watch cma.ca for further details!}

\section{Abstracts due 1 May 2006}

For more information on the Call for Papers or the conference, please contact Susan Yungblut at $800663-7336$ or $613731-8610 \times 2877$ or susan.yungblut@cma.ca or visit $\mathrm{cma} . \mathrm{ca} /$ physicianhealth\&well-being
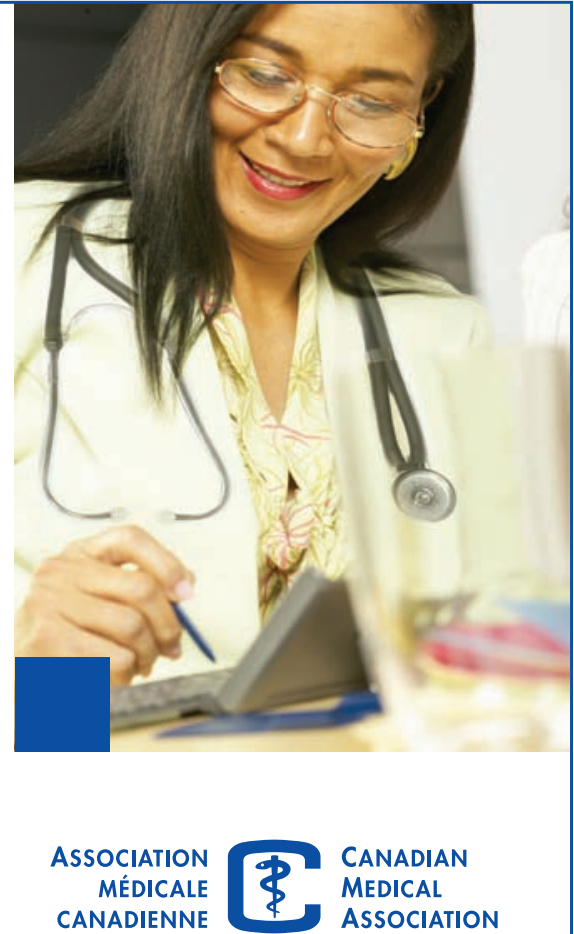

CANADIENNE

ASSOCIATION

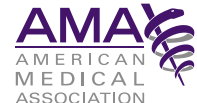

